DOI: 10.24234/wisdom.v17i1.430

Ganna PRIHODKO,

Oleksandra PRYKHODCHENKO,

Kateryna VASYLYNA

\title{
EMOTIONS OF MYSTERY IN GOTHIC NOVELS AND THRILLERS
}

\begin{abstract}
The article is dedicated to the study of the emotions of mystery in Gothic novels and thrillers. For many years, beginning with ancient times and up to modernity, mysteries and secrets were under thorough investigation by scientists. Mysteries, secrets and silence are associated with horror and happiness. That's why they became the object of the proposed article. According to the linguacultural approach, the concepts were studied as complex phenomena, with composite meaning peculiar to the concepts under analysis. The concepts MYSTERY, SILENCE and SECRET, were considered as the typical situations, the structure of which consists of such spheres: actants, predicates, attributes, quantifiers, space and time. Each of these spheres represents part of the characteristics and makes it possible to create a general understanding of the concepts under analysis as of complex phenomena, which are most vividly revealed in Gothic novels and thrillers. These novels disclose the emotions of mystery as unknown, horrific and tense situations are the main feature of these genres. Mystery has the key role here and is the inseparable part of their understanding. It was demonstrated that the concepts under analysis represent positive and negative features which denote their ambiguous and binary character at the same time.
\end{abstract}

Keywords: concept, frame structure, mystery, the Gothic novel, the thriller.

Introduction

The problem of existence, life and death, love, happiness and mystery has been under the analysis of scientists for a great number of years and centuries. The constant process of development and understanding of the world made people study everything which was strange and unknown to broaden the horizons of conscious and lessen the amount of foreign in our world. All these lead to the combination and merging of everything unfamiliar into one segment of reality. A lot of philosophic works were dedicated to this problem (Abbott, 2010; Schinkel, 2019, p.
293). As H. Lovecraft (2000) mentioned: "the oldest and strongest emotion of humanity is fear, and the oldest and strongest type of fear is the fear of the unknown" (p. 78).

According to the cognitive approach to language, the process of thinking appears due to the concepts, which are encoded with the help of verbal means. Language units represent different parts of the conceptual content of human consciousness and relate them to the semantics of one or other concepts.

Based on the psychological and philosophical approaches, the notion of the mystery or "suspense", which occupied one of the central 
places in psychology and psycholinguistics in 1980-1990 years, is determined as the emotional state, emotional reaction to the narration, emotion, which exists along with the development of actions (Bozhko, 2017, p. 38).

Research methods. The necessity of the complex analysis determined the usage of such methods of investigation as the method of general sampling and descriptive method - for inventorying and interpretation of the language units; conceptual analysis, in particular - frame modelling, for revealing of the semantic structure of the concepts under analysis; the analysis of the dictionary definitions to identify conceptual peculiarities, which are lexicalized; contextual analysis was used to study the language embodiment of concepts MYSTERY, SILENCE and SECRET in Gothic novels and thrillers.

\section{Results of the Study}

The semantical (component) (Alefirenko, 1999), (Popova \& Sternin, 2002) and contextual approaches (Karasik, 2012), (Kubrjakova, 1994) are used in the modern linguistics for the analysis of the language units' content and structure as well as for systematization of knowledge about them.

In our study, we use the linguacultural approach to the understanding of the concept, which is based on the notion that a concept is the basic unit of culture. Scientists agree that it is possible to distinguish informative, image and interpretational parts in the structure of each concept.

The informative (or notional) part is created by the complex of cognitive features, which correspond to the meaningful characteristics of the object of studying (object or phenomenon) from the speakers' point of view. The image compo- nent is formed via perceptive and cognitive images and unites perceptive (visual, auditory, olfactory, taste) cognitive features, which were created as a result of the metaphoric comprehension of the conceptualized notion. The interpretational (evaluative) part combines cognitive features, which correspond to the general, emotional, aesthetic and other evaluations of the speakers (Prykhodchenko, 2017, p. 58).

The study of the concepts MYSTERY, SILENCE and SECRET is topical because it was mentioned both by Ukrainian (Galych, 2011), (Lukin, 1992), (Yefymenko, 2015), and foreign (Hoffmann, 1982) scientists. The most peculiar, to our mind, is the understanding of the atmosphere of mystery in the Gothic novels and thrillers through the prism of emotions, as far as their obscure, mystical and irrational nature creates that atmosphere of terror and suddenness, which most fully reveals all the peculiarities of the concepts under analysis.

The aim of our study is discovering the peculiarities of emotional perception of the atmosphere of mystery in Gothic novels and thrillers.

The object of the study is the atmosphere of mystery in Gothic novels and thrillers.

The peculiarity of the emotional perception of the atmosphere of mystery in Gothic novels and thrillers is the subject of the study.

\section{Some Peculiarities of Gothic \\ Novels and Thrillers}

The gothic novel, as the variety of novels, was completely formed at the end of the XVIII century and was connected with the aesthetics of pre-romantics. One of the main peculiarities of this time was the interest in Gothic, which included not only the Mediaeval style of architecture but also the spirit and the gloomy mood of 
this epoch, the fantasy, chivalry, mysticism, fairytale character, horror and mystery.

According to E. Birkhead (1963), belief in the supernatural was transmitted from one generation to another during a long period of time, but the fear and horrific feelings, legends, which were connected to it, were not minimalized. They were transformed into literary works ( $\mathrm{p}$. 14). The constant connection between the person's understanding of the outer world and perception of strange, mysterious facts of reality is explained by the fact that "the initial function of the human psyche is implemented in the frames of the inner and first architectonical categorical opposition 'good - evil'” (Berestnev, 2000, p. 112).

H. Lovecraft expresses a similar understanding of the world in his works: "it is clear that horror literature is as old as the human mind or language. The cosmic horror appears as part of the earliest folklore of all nations. It is easy to notice it in the ancient ballads, chronicles and Holy Scriptures" (Lovecraft, 2000). Describing the story of gradual entrance of the "supernatural" into the literary works, H. Lovecraft (2000) recollects some ancient authors, west European Medieval epos, "The Divine Comedy" of the "pioneer in the classic mastering of the mysterious atmosphere - A. Dante", the poetry of E. Spenser, tragedies by W. Shakespeare and others. The researcher shows the natural character of the peoples' interest in everything, which is terrific. This fact gives an impulse to the literature of horror and finds its display in the literature of different times, and not only at the border of XVIII - XIX centuries (Prykhodchenko, 2017, pp. 46-48).

The thriller as a genre of literature comes from English "to thrill" - 'to cause to experience a sudden sharp feeling of excitement' (Merriam-
Webster Dictionaries online), and its main task is to cause the feeling of anxiety, agitation and fear, which are interchanged with happiness, and is characterized by critical feelings, which are peculiar to each stage of the plot development (D'jakova, 2013).

According to J. Patterson (2006), "if the thriller cannot tickle nerves, it means that it doesn't cope with its task". The main elements of this genre are mystery and tension. Due to them, the development of the plot is created, its tension and the unexpected finale, denouement of which becomes explicit only during the reading of the novel. All mentioned above makes the Gothic novels (B. Stoker "Dracula", S. King "Salem's Lot") and thrillers (T. Harris "Red Dragon" and "The Silence of the Lambs") the most actual material for the study of MYSTERY, SILENCE and SECRET concepts' verbalization.

\section{Frame Modeling of the Concepts MYSTERY, SILENCE and SECRET}

The most relevant for the study of the concepts MYSTERY, SILENCE and SECRET will be the frame modelling. Frame, in our work, is understood as the typical situation, which "is connected with real psychological processes of perception, belongs to the inner layer of social consciousness and is characterized by such features as schematic and rootedness in the consciousness of the members of the society" (Selivanova, 2000, p. 101).

In general, concepts MYSTERY, SILENCE and SECRET are analyzed as situations, the definitions of which are given in the dictionary, for example, 'silence' - 'the quality or state of being mostly or completely unknown", 'mystery' - "something hard to understand or explain" and 'secret' - "not known or meant to be 
known by the general populace; something hard to understand or explain" (Macmillan Dictionaries online). The concept of SILENCE is the most general one, according to its meaning, and combines all the characteristics, which are peculiar to other concepts under analysis.

If we speak about the etymology of the lexemes under analysis, the oldest usage of the lexeme 'mystery' (dating back to the $14^{\text {th }}$ century) was its association with the region - 'religious truth via divine revelation, hidden spiritual significance, mystical truth'; lexeme 'secret' (beginning with the $14^{\text {th }}$ century) was used to denote something concealed, private - 'set apart, hidden, private'; lexeme 'silence' (since 1200) denoted silence - 'state of being silent' (The Etymological Dictionary of the English Language).

The content of the concepts MYSTERY, SILENCE and SECRET is determined via semantic analysis of the key nominations of the concepts (their names) and systematization of cognitive features, which reflect the parameters of the conceptualization of such phenomena as mystery, silence and secret and are understood by the culture's bearers.

In order to find out the key names and other nominations of the concepts MYSTERY, SILENCE and SECRET the data from different lexicographic sources are analyzed with the help of the method of general sampling. The language unit receives the status of the name of the concept according to the next criteria: it should be from the lexico-grammatical class of nouns; it should have an abstract meaning, functional neutrality, duration of existence in the language system and the high level of adoption (which is represented by the productivity in the process of word-creation and presence of phraseological units (Prykhodchenko, 2017, p. 62).

The names of the concepts MYSTERY,
SILENCE and SECRET are presented by the nouns mystery, silence and secret. Firstly, these nouns are abstract and denote such notions as 'events', 'state' and 'mystery', i.e. the characteristics of realia - mystery "an unexplained or inexplicable event", silence "the condition or quality of being or keeping still and silent", secret "a mystery".

Secondly, they are the main units in the rows of synonyms (mystery - enigma, problem, riddle etc.; silence - muteness, peace, secretiveness, stillness etc., secret - code, enigma, puzzle, mystery, secrecy etc.), and in the functional sense, they are characterized by neutrality.

Thirdly, the units mystery, silence and secret are stable and function in the system of the English language during a long period of time: mystery from Engl. misterie "close eyes", silence from Engl. silence "to be silent", a secret from Engl. sèrētus "to set aside" (The Free Dictionary).

One more evidence of the fact that the process of conceptualization and forming of the concept's name has being finished is the word-forming productivity of lexical units. The development of the word-forming and semantical derivatives and also the inclusion of the lexeme into the structure of phraseological units, which occurs only after the deepening of the notion: mystery $>$ mysteries, mysterious, mysteriously, mystic, mystical etc., wrapped in a mystery, a mystery to (one) etc.; silence > silent, silently, silencer; code of silence, the conspiracy of silence, silence is gold etc.; secret > secrecy; best-kept secret, dark secret etc. (The Free Dictionary).

In order to study the peculiarities of the concepts MYSTERY, SILENCE and SECRET the Gothic novels and thrillers were chosen, as far as the atmosphere of mystery and obscurity is represented there most fully and vividly. 
The analysis of the concepts MYSTERY, SILENCE and SECRET in the texts of the Gothic novels and thrillers confirms the relevant character of the key verbalizers mystery, silence and secret both for Gothic linguoculture and for the space of thrillers. On the one hand, these units are characterized by the highest index of usage in the texts under analysis (mystery - 41, secret 62, silence-193).

On the other hand, they are the productive base for creating other nominations of concepts: silent, silently, silences, silencer, silenced, mysteries, mysterious, mystifying, mysteriously, mystical, secrecy, secretly, secretive, secretively, secrets, desecrate, desecration.

The system of direct nominations of concepts is enriched with the help of phraseological units:

"be a mystery to sb" (Stoker, 1994, p. 32;

King, 2011, p. 9), "heart of a mystery" (Stoker, 1994, p. 50), "held up finger for silence" (Harris, 2002, p. 100), "years of silence" Harris, 2002, p. 110), "in silence" (King, 2011, p. 134; Stoker, 1994, pp. 34, 41, 103; Harris, 2002, p. 223; Harris, 2000, pp. 171, 233), "stay in silence" (Stoker, 1994, p. 13), "keep silence" (Stoker, 1994, pp. 216, 258; King, 2011, p. 172), "break the silence" (Harris, 2000, p. 151; Stoker, 1994, pp. 178, 181), "keep a secret" (Harris, 2002, p. 114; Harris, 2000, p. 39; Stoker, 1994, pp. 47, 128; King, 2011, pp. 146, 280), "in secret" (Stoker, 1994, pp. 27, 175).

The most frequent amount of usage of lexeme silence proves our thought that the concept of SILENCE is the most generalized one and includes the characteristics of other concepts under analysis - MYSTERY and SECRET. The fragments of information, which are included in the content of some concept, are characterized as the general unit and exist in some particular in- terrelation. But, different concepts are described with fragments, which are peculiar only to them.

\section{Spheres of the Concepts MYSTERY, SILENCE and SECRET}

According to scientists (Kozlova, 2015), the most effective spheres in studying the concepts MYSTERY, SILENCE and SECRET were singled out: actants, predicates, attributes, quantifiers, space and time. They were chosen because they reveal all the peculiarities of the concepts under analysis most vividly and fully, show their interconnection and opposition.

\section{ACTANTS of the Concepts MYSTERY, SILENCE and SECRET}

ACTANTS of the spheres MYSTERY, SILENCE and SECRET indicate their connection with mystery, uncertainty and secrecy, which is verbalized with the help of nouns denoting people or proper names:

"...write to Mr Hawkins ... in secret..." (Stoker, 1994, p. 27), "Professor wished ... kept secret” (Stoker, 1994, p. 128), "The Count shall not yet know my secret" (Stoker, 1994, p. 34), “Count's mystery frightened me" (Stoker, 1994, p. 30), “...the secrets of God" (Stoker, 1994, p. 88), "father ... kept the secret" (King, 2011, p. 34).

It is necessary to mention that in one of the analyzed novels ('Salem's Lot' by S. King), the city itself was characterized as a living creature, which was obliged to keep its secrets, to conceal everything, known because of vampire Barlow's arrival to the city and all his deeds

"These are the town's secrets, and some will later be known and some will never be known" (King, 2011, p. 147). 
With the help of personal ("I know the secret now..." (Stoker, 1994, p. 72), possessive (“...yet know my secret” (Stoker, 1994, p. 34), “...learn his secrets" (Stoker, 1994, p. 205), “...kept its secrets" (King, 2011, p. 280), “...takes their silence" (Stoker, 1994, p. 53), "...to notice my silence" (Stoker, 1994, p. 171), "...of a silent mystery of their own" (Stoker, 1994, p. 219), and indefinite ("there should be no secret..." (Stoker, 1994, p. 88), "we need have no secrets" (Stoker, 1994, p. 190), “...that's no secret" (Harris, 2002, p. 83) pronouns demonstrative determiners ("...of this mystery" (Stoker, 1994, p. 178), “...this silence” (Harris, 2000, p. 132) the belonging of secrets, mysteries and silences to some specific people or their complicity to them is shown.

The usage of the definite article the is the indicator of the fact that spheres MYSTERY, SILENCE and SECRET enclose some concrete realia

"...all that broke the silence" (Harris, 2000, p. 151), “...the mean secrets of his life" (King, 2011, p. 221), “...of the terrible mystery...” (Stoker, 1994, p. 128).

Abstract nouns burden ('a source of great worry'), spell ('a bewitched state or trance'), net ('sth that entraps'), beat ('pulsation or throb') are used to denote everything unknown and horrific, which is usually peculiar to mysteries, silence and secrets:

"...burden of silence" (Stoker, 1994, p. 222), “...secret of darkness" (King, 2011, p. 286), "...spell of silence" (Stoker, 1994, p. 180), "...horrible net of gloom and mystery” (Stoker, 1994, p. 27), “...beats of silence" (Harris, 2002, p. 4).

The combination of the noun silence with the word-combination weed-choked back yard intensifies that unpleasant, mysterious and depressive atmosphere, which was created with the help of concepts under analysis -

"Ben Mears stood in the great silence of

the weed-choked back yard..." (King,

2011, p. 231).

So, the usage of the nouns, which denote the people or proper names, personal, possessive and indefinite pronouns and also demonstrative determiners, the definite article the and abstract nouns shown the mysterious and not certain character of the concepts MYSTERY, SILENCE and SECRET in the novels under analysis.

\section{PREDICATES of the Concepts MYSTERY, SILENCE and SECRET}

PREDICATES of the concepts MYSTERY, SILENCE and SECRET mostly represent either the action or the state, which are shown with the help of the active or passive voice of the verbs.

For the representation of the analyzed concepts, the words of mental activity (know, notice etc.) are used. They indicate some degree of understanding and knowledge:

“know ... secret" (Stoker, 1994, p. 34),

"know ... mystery" (Stoker, 1994, p. 163),

"to notice silence" (Stoker, 1994, p. 171).

The verbs of physical activity (drive, come, return, ride) indicate the length and duration of mysterious things and atmosphere in time (for example, during the journey):

"drove in silence" (King, 2011, p. 176), "come in secret" (Stoker, 1994, p. 15), "in silence we retuned" (Stoker, 1994, p. 41), “...had ridden in silence" (Harris, 2000, p. 171).

The verbs, which indicate the ending of something (end, break) is explained by the fact that everything strange, unknown and mysterious has its final point, after which everything became vivid and clear: 
"the silence was broken" (Stoker, 1994, p.

178), "all that broke the silence" (Harris, 2000, p. 151), "to end this mystery" (Stok-

er, 1994, p. 163).

The proof of this fact is the usage of the verb see, which means 'to come to know':

"had seen ... secrets" (King, 2011, p.

286).

So, the predicates, which are used to denote the concepts MYSTERY, SILENCE and SECRET, confirm their mysterious and uncertain characters, but, at the same time, they denote their duration and possibility of an investigation.

\section{ATTRIBUTES of the Concepts MYSTERY, SILENCE and SECRET}

ATTRIBUTES of the concepts MYSTERY, SILENCE, and SECRET reveal the meaningful and inalienable features of the actualized phenomena with the help of adjectives, which correlate with different categories.

Qualitative adjectives are used more often for the representation of the analyzed concepts to denote both positive (new, blessed) and negative (uncomfortable, agonizing) evaluation of the sphere of mystery. Direct, immediate characteristics of objects and phenomena are also represented with their help.

All concepts under analysis are, to some extent, defined by adjectives with negative meaning. All of them are characterized by more or less degree of 'mystery' and 'horror'. SILENCE is depicted as uncomfortable, such as warns about something (usually about the danger) - warning, agonizing, dogged, profound, desert, utter, hunched, awful, heavy, eerie, grim, dead, big, aching, void:

"uncomfortable silence" (King, 2011, p.

137), "warning silence" (Stoker, 1994, p.

269), "agonizing silence" (Stoker, 1994, p.
236), "dogged silence" (Stoker, 1994, p.

229), "profound silence" (Stoker, $1994 \mathrm{p}$.

219), "desert silence" (King, 2011, p. 8),

"utter silence" (King, 2011, pp. 13, 42),

"hunched silence" (King, 2011, p. 77),

"awful heavy silence" (King, 2011, p.

118), "eerie silence" (King, 2011, p. 264),

"grim silence" (Stoker, 1994, p. 11),

"dead, grim silence" (Stoker, 1994, p.

300), "silence - big, aching, void ..."

(Stoker, 1994, p. 180).

But, there are also adjectives with positive meaning, which characterize the concept SILENCE - "blessed silence" (Harris, 2002, p. 223), to denote the blissful silence, which brings the end to the sorrows and torments, and also, to show the respect to the dead people -

"in respectful silence we took the places

assigned to us close to the tomb" (Stoker,

1994, p. 179).

Attributes, which indicate the concepts MYSTERY and SECRET, appear not so frequent, but they also give both positive - "new mystery" (Stoker, 1994, p. 141) (the new mystery can be good and not terrific), and negative characteristics - dark - "dark mystery" (Stoker, 1994, p. 190), deep, dark, mean, embarrassing “deep, dark secret" (King, 2011, p. 27), “mean secret" (King, 2011, p. 212), "embarrassing secrets" (Harris, 2002, p. 19).

The usage, mostly, of the adjectives with negative meaning for indicating the features of the analyzed concepts, underlines the fact that mystery evokes anxiety, uncomfortable feelings and fear, which are the result of negative emotions caused by them.

$$
\begin{aligned}
& \text { QUANTIFIERS of the Concepts } \\
& \text { MYSTERY, SILENCE and SECRET }
\end{aligned}
$$

QUANTIFIERS of spheres MYSTERY, 
SILENCE and SECRET are represented by the denotation of quantitative relations. The verbalizers are non-productive and, in most cases, refer to the plurality of the notions under analysis, in particular, by the usage of the pronoun all - "all the secrets" (King, 2011, pp. 107, 122), "all our secrets" (Stoker, 1994, p. 46), word-combination one more (which shows the presence of some similar objects or notions) - "one more mystery" (Stoker, 1994, p. 73), and pronoun another 'one more, an additional' - "another silence" (Harris, 2000, p. 45).

The indication of the possibility of multiple usages of the notions under analysis underlines the reality of peoples' fear about the uncertain and unclear character of events, which can be caused by these phenomena.

\section{SPACE and TIME of the Concepts MYSTERY, SILENCE and SECRET}

The verbalizers of SPACE and TIME were effective only for the concept SILENCE, which can be explained by the fact that this concept is the most frequent in the analyzed novels and combines the characteristics of two other concepts.

SPACE of the sphere SILENCE is represented by the description of:

- 'closed, limited' space (inside) - "silence in the room" (King, 2011, p. 217), "silence fell in the room" (King, 2011, p. 246), "silence ... for one floor" (Harris, 2000, p. 66);

- 'restricted' space - "silence inside her" (King, 2011, p. 229), "silence over everything" (Stoker, 1994, p. 219);

- 'open' space (outside) - “...silence of the night' (Stoker, 1994 p. 183).

The presence of verbalizers, which characterize space both as closed/restricted and open, means that silence is all-absorbing. It is present in all places and spheres of our lives and influences our understanding of the outer world, filling it with some uncertainty and mystery.

TIME of the Sphere SILENCE is Represented with the Help of such Means:

- nouns moment, couple and adverbs, which are used to denote very short periods of time:

"a moment of silence" (King, 2011, p. 205), "for a couple of minutes there was silence" (Stoker, 1994, p. 244), "during his silence" (Stoker, 1994, p. 290), "through the silence of the night" (Stoker, 1994, p. 300);

- the noun years to denote the period of time, which lasts for several years - "years of silence" (Harris, 2002, p. 110);

- adverbs, which contain the seme 'starting point' in their lexical meaning and are used to show the border with other actions after, until, hereafter, till:

"after a few minutes' silence" (Stoker, 1994, p. 63), “...in silence until they were on the turnpike" (King, 2011, p. 176), "...silence until he asked again" (Stoker, 1994, p. 176), "hereafter in the silence" (Stoker, 1994, p. 183), "silence, that lasted till we entered ..." (Stoker, 1994, p. 201);

- word-combinations which denote the beginning of some specific period of time: "silence ... for the ten minutes..." (King, 2011, p. 46), “...the silence ... into the day" (King, 2011, p. 212), “...half an hour of silence" (Harris, 2000, p. 95), "...for three hours in silence" (Harris, 2000, p. 233).

The verbalizers for the sphere SILENCE show its transience and the presence of some 
starting point, which means its duration at the same time.

\section{Personification of the Concepts MYSTERY, SILENCE and SECRET}

It should be noted that all three concepts are verbalized with the help of personification - they are provided with some characteristics of alive creatures. For example, the sphere SILENCE is represented as the one that:

- can move: with the help of verbs of motion 'creep back' - to crawl with the body near to or touching the ground backwards, 'follow' - to go after, 'descend' - to move from a higher to a lower place:

"silence crept back" (King, 2011, p. 212), "silence follows..." (Harris, 2002, p. 4), "silence descended..." (King, 2011, p. 181);

- can be static: with the help of verbs 'lay' to stay in a particular position, 'spun out' to prolong or extend:

"silence lay..." (King, 2011, p. 13), "the silence spun out" (King, 2011, p. 141);

- is possible to feel: with the help of verbs, which denote human feelings 'listen', 'feel:

"listen to the silence" (King, 2011, pp. 229, 193), "...felt its silence" (Harris, 2002, p. 37);

- can horrify: 'startle' - to alarm or frighten: “silence startled" (Stoker, 1994, p. 219);

- can jeer at somebody ('mock'), make some pressure ('press on') and stay above ('behind')"

"silence can mock" (Harris, 2002, p. 101), "silence pressed on them" (King, 2011, p. 156), "silence behind him" (Harris, 2002, p. 115).

Sphere MYSTERY is understood as the part of something alive, which is proved by the usage of the lexeme 'heart' to denote the living creature, which has the heart - the main organ of human's body functioning, the presence of the possibility to exist and feel:

"the heart of this mystery" (Stoker, 1994, p. 50).

Sphere SECRET is also compared with the living creature, which can be 'betrayed' or 'woken up':

“betray ... a secret" (Stoker, 1994, p. 128),

“wakened a secret" (King, 2011, p. 32).

It is also interesting to mention that all the concepts under analysis are connected with the atmosphere of fear, horror and uncertainty.

As illustrated in the example, some secret has changed the existing fear into terror in people's eyes, which was caused by the fact of nonunderstanding and obscurity:

"They looked into each other's eyes and saw that fear had been changed to near terror by some secret' (King, 2011, p. 68).

Sphere SECRET is connected with such lexemes as hell ('the place of eternal punishment for the wicked after death'); darkness ('opposite of light part of the day, usually characterized by sth scaring'), the devil ('the major personified spirit of evil, ruler of hell'):

"all the secrets of hell' (King, 2011, p.

122), "all the secrets of darkness" (King,

2011, p. 286), “...his secrets...where the

devil claims..." (Stoker, 1994, p. 205).

Sphere SILENCE is used along with adjectives marked - 'clearly defined and evident, noticeable' and eerie - 'inspiring inexplicable fear, dread or uneasiness':

"the silence was so marked..." (Stoker, 1994, p. 65), "the house had eerie silence" (King, 2011, p. 264).

Sphere MYSTERY is marked with the help of adjective silent - 'characterized by the absence or near absence of noise or sound', dark- 
'sullen or threatening', terrible - 'causing great fear or alarm', which shows the silent, concealed, dark and horrific character of mysteries:

"...merged together in one silent mystery"

(Stoker, 1994, p. 79), “...to this dark mystery” (Stoker, 1994, p. 190), “...utter ignorance of the terrible mystery" (Stoker, 1994, p. 128).

This connection proves the mysterious and uncertain character, which is peculiar to the spheres of MYSTERY, SILENCE and SECRET, and changes into the lack of understanding and fear in front of those things, which are concealed by secrets, silence and mysteries, as far as they are unknown and evoke the natural selfpreservation instinct.

\section{Conclusion}

All the concepts, which are represented in the analyzed novels, are characterized both form the positive and negative sides. This is determined by peculiarities of the genre of thrillers and Gothic novels, the main feature of which is to conceal the mystery and to keep the intrigue up to the end of the story. The perspective is the analysis of the representation of fears, which are caused by the atmosphere of mystery.

\section{References}

Abbott, M. (2010). The Poetic Experience of the World. International Journal of Philosophical Studies, 18(4), 493-516.

Alefirenko, N. F. (1999). Spornye problemy semantiki (Disputable Questions of Semantics, in Russian). Volgograd: Peremena.

Berestnev, G. I. (2000). Samosoznanie lichnosti $v$ zerkale jazyka (The Self-Consciousness of a Person in the Mirror of Lan- guage, in Russian). (Doctoral Dissertation, Moscow State University). Retrieved from https://www.dissercat.com/content/samosoznanie-lichnosti-vzerkale-yazyka.

Birkhead, E. (1963). The Tale of Terror. A Study of the Gothic Romance. New York: Russell \& Russell Inc.

Bozhko, O. S. (2017). Lingval'na reprezentacija atmosfery SASPENS $v$ anglomovnyh hudozhnih tvorah zhanru horror: semantyko-kognityvnyj aspekt (Lingual Representation of the Suspense Atmosphere in English Horror Fiction: Semantic-Cognitive Aspect, in Ukrainian). ( $\mathrm{PhD}$ dissertation, Kherson State University). Retrieved from http://www.kspu.edu/FileDownload.ashx/\% D0\%91\%D0\%BE\%D0\%B6\%D0\%BA $\% \mathrm{D} 0 \% \mathrm{BE} \% 20 \% \mathrm{D} 0 \% 9 \mathrm{E} . \% \mathrm{D} 0 \% \mathrm{~A} 1$. $\% \mathrm{D} 0 \% 90 \% \mathrm{D} 0 \% \mathrm{~B} 2 \% \mathrm{D} 1 \% 82 \% \mathrm{D} 0 \% \mathrm{~B}$ E\%D1\%80\%D0\%B5\%D1\%84\%D0\% B5\%D1\%80\%D0\%B0\%D1\%82 \%20 $\% \mathrm{D} 1 \% 81 \% \mathrm{D} 0 \% \mathrm{~B} 0 \% \mathrm{D} 0 \% \mathrm{~B} 9 \% \mathrm{D} 1 \% 8$ 2.pdf?id=a4eb2cc3-9f9b-404c-a5ce$873709 \mathrm{c} 14114$.

D'jakova, T. V. (2013). Harakteristika zhanra "triler" $i$ ego podzhanry (The Characteristics of the Genre "Thriller" and Its Sub-Genres, in Ukrainian). Lingua Mobilis. The Language of the Literary Works, 5(44), 32-36.

Galych, O. B. (2011). Movni zasoby vidtvorennja mistychnogo $v$ anglijs'komu gotychnomu romani XVIII st. (Language Means of Representation of Mystical in English Gothic Novel of XVIII Cent, in Ukrainian). (PhD dissertation, Kyiv National Linguistic University).

Harris, Th. (2000). Red Dragon. Canada: Dutton. 
Harris, Th. (2002). The Silence of the Lambs. New York: Arrow Books.

Hoffmann, G. (1982). The Fantastic in Fiction: Its "Reality" Status, Its Historical Development and Its Transforation in Postmodern Narration. Yearbook of Research in English and American Literature, 1, 273-275.

Karasik, V. I. (2012). Semioticheskie tipy konceptov (Semiotic Types of Concepts, in Russian). Question of Cognitive Linguistics, 4, 5-11.

King, S. (2011). Salem's Lot. New York: Anchor.

Kozlova, T. O. (2015). Ikonichnist u leksytsi indoievropeiskoi pramovy (Iconicity in the Lexicon of Indo-European Pra-Language, in Ukraininan). Zaporizhzhia: Kruhozir.

Kubrjakova, E. S. (1994). Nachal'nye etapy stanovlennya kognitivizma: lingvistika, psihologiya, kognitivnaya nauka (Initial Stages of Formation of Cognitivizm: Linguistics, Psychology, Cognitive Science, in Russian). Questions of Linguistics, 4, 34-38.

Lovecraft, H. P. (2000). The Annotated Supernatural Horror in Literature. New York: Hippocamus Press.

Lukin, O. O. (1992). U mahichnomu labirynti svidomosti. Literaturnyi mif XX st. (In the Magical Labyrinth of Consciousness. Literary Myth of XX Cent, in Ukrainian). Foreign Literature, 3, 234249.

Macmillan Dictionaries online. Retrieved from http://www.macmillandictionary.com.

Merriam-Webster Dictionaries online. Retrieved from https://www.merriam-webster.com.
Patterson, J. (2006). Thriller. Ontario, Canada: MIRA Books.

Popova, Z. D., \& Sternin, I. A. (2002). Ocherki po kognitivnoi lingvistike (Outlines about Cognitive Linguistics, in Russian). Voronezh: Istoki.

Prykhodchenko, O. O. (2017). Kontseptualna opozytsiia ZhYTTIa - SMERT v hotychnii kartyni svitu (na materiali anhliiskomovnykh romaniv pro vampiriv) (The Conceptualization of the Opposition LIFE - DEATH in the Gothic Worldview (Based on the English Novels about Vampires, in Ukrainian). $(\mathrm{PhD}$ dissertation, Zaporizhzhia National University). Retrieved from http://phd.znu.edu.ua/page//aref/02_20 17/Prykhodchenko aref.pdf.

Schinkel, A. (2019). Woder, Mystery, and Meaning. Philosophical Papers, 48(2), 293319.

Selivanova, E. A. (2000). Kognitivnaya onomasiologiya (Cognitive Onomasiology, in Russian). Kyiv: Fitosotsiotsentr.

Stoker, B. (1994). Dracula. England: Penguin books.

The Etymological Dictionary of the English Language. Retrieved from https://www.etymonline.com.

The Free Dictionary. Retrieved from http://www.thefreedictionary.com.

Yefymenko, T. M. (2015). Zasoby vyrazhennia linhvistychnykh katehorii fantastychnoho, mistychnoho, taiemnychoho $v$ anhliiskykh hotychnykh romanakh XVIIIst (The Means of Representation of Linguistic Category of Mystical in English Gothic Novels of XVIII Cent., in Ukrainian). Odessa Linguistic Journal, 5(2), 43-47. 